\title{
SALIVARY COMPONENTS OF TREATED CANCER PATIENTS AND PATIENTS WITH PRECANCEROUS LESIONS
}

\author{
Assya Krasteva ${ }^{1}$, E. Aleksiev², A. Ivanova ${ }^{3}$, I. Altankova ${ }^{4}$, T. Bocheva ${ }^{4}$, Pavel \\ Stanimirov ${ }^{2}$, A. Bobeva ${ }^{2}$, Nikolai Yanev ${ }^{2}$, Angelina Kisselova ${ }^{1}$ \\ ${ }^{1}$ Department of Oral Diagnostic and Maxillofacial Radiology, Faculty of Dental \\ Medicine, Medical University, Sofia, Bulgaria \\ ${ }^{2}$ Specialized University Hospital for Active Treatment in Maxillofacial Surgery, \\ Sofia, Bulgaria \\ ${ }^{3}$ Clinic of Gastroenterology, "St. Ivan Rilski" University Hospital, Medical \\ University, Sofia, Bulgaria \\ ${ }^{4}$ Laboratory of Immunology, "St. Ivan Rilski” University Hospital, Medical \\ University, Sofia, Bulgaria
}

\section{SUMMARY}

Oral squamous cell carcinoma (OSCC) accounts for nearly $50 \%$ of all newly diagnosed cancers in India. In Bulgaria OSCC reaches nearly $75 \%$ of malignant tumours in the oral cavity (Ugrinov, 2006). The prognosis of this cancer remains relatively unchanged for the past 30 years, despite advances in diagnosis and management.

Salivary analysis holds promise as a non-invasive approach to identify biomarkers for human oral cancer. Salivary levels of immunoglobulins and acute phase proteins may have significant prognostic value in early cancer diagnostics.

Key words: saliva, oral cancer patients, proteins

\section{INTRODUCTION}

Oral malignancy represents a serious public health problem. Oral squamous cell carcinoma is one of the leading causes for death in France. In Bulgaria OSCC reaches nearly $75 \%$ of malignant tumors in the oral cavity. Survival rates for OSCC patients have remained relatively unchanged for the past 30 years, despite advances in diagnosis and management.

\section{AIM}

This study aimed to investigate a large constellation of proteins taking part in immune mechanisms in oral neoplastic disease.

\section{MATERIALS AND METHODS}

Patients were recruited from the Specialized University Hospital for Active Treatment in Maxillofacial Surgery, Sofia for a period of 28 months. 35 patients with histologically confirmed OSCC (untreated OSCC patients), 10 patients with precancerous lesions, 15 treated OSCC patients and 31 healthy controls were included in the study. The demographic and clinical characteristics of the studied individuals are given in Table 1 and Table 2. None of the untreated OSCC patients had received any prior chemotherapy, radiotherapy, surgery or alternative treatment.

Table 1. Demographic data of the studied individuals

\begin{tabular}{|l|c|c|c|c|}
\hline & $\begin{array}{c}\text { OSCC } \\
\text { untreated }\end{array}$ & $\begin{array}{c}\text { OSCC } \\
\text { treated }\end{array}$ & $\begin{array}{c}\text { Precancerous } \\
\text { lesions }\end{array}$ & Controls \\
\hline males & 25 & 10 & 5 & 9 \\
\hline females & 10 & 5 & 5 & 22 \\
\hline yrs & $56(40-77)$ & $58(42-76)$ & $46(22-72)$ & $35(18-75)$ \\
\hline
\end{tabular}

Table 2. Clinical characteristics of the studied individuals

\begin{tabular}{|l|l|l|l|}
\hline & OSCC untreated & OSCC treated & Precancerous lesions \\
\hline & $12-$ ca fundi cavi oris & & \\
Characteristic & $11-$ ca linguae & 1 pt - chemotherapy & 3 pts- lichen planus \\
& 8 - ca gingivae & $8 \mathrm{pts}-$ radiotherapy & 7 pts - leukoplakia \\
& 2 ca labii oris & & \\
& $1-$ ca oropharyngis & & \\
\hline
\end{tabular}




\begin{tabular}{|c|c|c|}
\hline Differentiation & $\begin{array}{l}14 \text { pts - well } \\
15 \text { pts - moderate } \\
6 \text { pts - poor }\end{array}$ & $\begin{array}{l}6 \text { pts - well } \\
6 \text { pts - moderate } \\
3 \text { pts - poor }\end{array}$ \\
\hline
\end{tabular}

The data of 31 disease free subjects were used as controls. Each healthy individual underwent a face and mouth examination by a surgeon and a dentist to ensure that suspicious mucosal lesions, as well acute and chronic parodontitis were not present. All control individuals had not received any medication one month prior to the study. None of the studied subjects had a history of any chronic disease, prior malignancy, immunodeficiency and autoimmune disorders. All patients and controls gave informed consent.

\section{Collection of the samples}

Whole unstimulated salivary probe was collected as described by Dawes and Weatherell.

\section{Determination of IgA and IgG in saliva}

The levels of $\operatorname{IgA}$ and $\operatorname{IgG}$ were assessed by radial immunodiffusion with high sensitivity by Manchini (Immunotest kits, Sofia, Bulgaria).

Determination of haptoglobin and CRP

The levels of haptoglobin and CRP in saliva were determined by imunoturbidimetric method. Salivary samples were centrifuged at $10000 \mathrm{~g}$ for $10 \mathrm{~min}$ to avoid visible precipitates. Cobas Integra 400 - Roche Diagnostic analyser was used (lower detection limit for haptoglobin was 0.102 $\mathrm{g} / \mathrm{l}$ and for CRP $0.85 \mathrm{mg} / \mathrm{l})$.

\section{Determination of total protein}

Total protein was determined by colorimetric method using Cobas Integra 400 - Roche Diagnostic analyzer (lower detection limit $0.8 \mathrm{~g} / \mathrm{l})$.

\section{Statistical analysis}

Statistical analysis was performed using SPSS package. Mann-Whitney U test was used for comparison of the data between tested groups and values lower than $0.001(p<0.001)$ were considered statistically significant.

\section{RESULTS}

OSCC untreated patients:

- versus controls:

Statistically significant increase of salivary total protein, $\operatorname{IgG}$, IgA, haptoglobin and CRP were found in untreated OSCC patients compared to control group (Table 3).

OSCC treated patients:

- versus controls:

In treated cancer patients only salivary level of total protein, $\operatorname{IgG}$ and $\operatorname{IgA}$ remain significantly higher $(\mathrm{p}<0.05)$. Significant decrease of salivary haptoglobin level is observed (Table 3).

Table 3. Alterations of salivary proteins in untreated OSCC versus control subjects and OSCC treated patients versus control subjects. Results are expressed by median

\begin{tabular}{|l|l|l|l|l|l|}
\hline $\begin{array}{l}\text { Parameters/ } \\
\text { Patients }\end{array}$ & $\begin{array}{l}\text { Total } \\
\text { protein } \\
(\mathrm{g} / \mathrm{l})\end{array}$ & $\begin{array}{l}\text { IgG } \\
(\mathrm{mg} / \mathrm{l})\end{array}$ & $\begin{array}{l}\text { IgA } \\
(\mathrm{mg} / \mathrm{l})\end{array}$ & $\begin{array}{l}\text { Haptoglobin } \\
(\mathrm{mg} / \mathrm{l})\end{array}$ & $\begin{array}{l}\text { CRP } \\
(\mathrm{mg} / \mathrm{l})\end{array}$ \\
\hline $\begin{array}{l}\text { OSCC untreated } \\
(\mathbf{n}=\mathbf{3 5})\end{array}$ & $\begin{array}{l}\mathbf{2 , 8} \\
\mathbf{p}=\mathbf{0 , 0 0 2}\end{array}$ & $\begin{array}{l}\mathbf{3 8} \\
\mathbf{p}=\mathbf{0 , 0 0 0}\end{array}$ & $\begin{array}{l}\mathbf{1 5 2} \\
\mathbf{p}=\mathbf{0 , 0 0 0}\end{array}$ & $\begin{array}{l}\mathbf{3 0} \\
\mathbf{p}=\mathbf{0 , 0 0 6}\end{array}$ & $\begin{array}{l}\mathbf{0 , 1 5 7} \\
\mathbf{p}=\mathbf{0 , 0 0 4}\end{array}$ \\
\hline $\begin{array}{l}\text { Controls } \\
(\mathrm{n}=31)\end{array}$ & 1,2 & 22 & 83 & 15 & 0,030 \\
\hline $\begin{array}{l}\text { OSCC } \\
\text { treated }\end{array}$ & $\begin{array}{l}\mathbf{2 , 1} \\
\mathbf{p}=\mathbf{0 , 0 4 4}\end{array}$ & $\begin{array}{l}\mathbf{9 0} \\
\mathbf{p}=\mathbf{0 , 0 0 1}\end{array}$ & $\begin{array}{l}\mathbf{1 3 0} \\
\mathbf{p}=\mathbf{0 , 0 3 7}\end{array}$ & $\begin{array}{l}\mathbf{0} \\
\mathbf{p}=\mathbf{0 , 1 2 1}\end{array}$ & $\begin{array}{l}\mathbf{0 , 1 4 0} \\
\mathbf{p}=\mathbf{0 , 3 6 0}\end{array}$ \\
\hline
\end{tabular}

- versus OSCC untreated patients:

Haptoglobin in saliva was significantly higher in OSCC untreated patients, compared to OSCC treated patients. No significant differences were found in the other salivary components (Table 4). 
Table 4. Alterations of salivary proteins in OSCC untreated versus OSCC treated. Results are expressed by median

\begin{tabular}{|l|l|l|l|l|l|}
\hline $\begin{array}{l}\text { Parameters/ } \\
\text { Patients }\end{array}$ & $\begin{array}{l}\text { Total protein } \\
(\mathrm{g} / \mathrm{l})\end{array}$ & $\begin{array}{l}\text { IgG } \\
(\mathrm{mg} / \mathrm{l})\end{array}$ & $\begin{array}{l}\mathrm{IgA} \\
(\mathrm{mg} / \mathrm{l})\end{array}$ & $\begin{array}{l}\text { Haptoglobin } \\
(\mathrm{mg} / \mathrm{l})\end{array}$ & $\begin{array}{l}\text { CRP } \\
(\mathrm{mg} / \mathrm{l})\end{array}$ \\
\hline $\begin{array}{l}\text { OSCC } \\
\text { untreated } \\
(\mathrm{n}=35)\end{array}$ & 2,8 & 38 & 152 & 30 & 0,157 \\
\hline $\mathrm{p}$ & $\mathrm{p}=0,293$ & $\mathrm{p}=0,432$ & $\mathrm{p}=0,375$ & $\mathrm{p}=0,007$ & $\mathrm{p}=0,144$ \\
\hline $\begin{array}{l}\text { OSCC } \\
\text { treated }\end{array}$ & $\mathbf{2 , 1}$ & $\mathbf{9 0}$ & $\mathbf{1 3 0}$ & $\mathbf{0}$ & $\mathbf{0 , 1 4 0}$ \\
\hline
\end{tabular}

Patents with precancerous lesions

- versus controls:

IgG and IgA were significantly increased in patient with precancerous lesions (Table 5).

Table 5. Alterations of salivary proteins in in patients with precancerous lesions versus untreated OSCC patients and control subjects. Results are expressed by median

\begin{tabular}{|l|l|l|l|l|l|}
\hline $\begin{array}{l}\text { Parameters/ } \\
\text { Patients }\end{array}$ & $\begin{array}{l}\text { Total protein } \\
(\mathrm{g} / \mathrm{l})\end{array}$ & $\begin{array}{l}\mathrm{IgG} \\
(\mathrm{mg} / \mathrm{l})\end{array}$ & $\begin{array}{l}\mathrm{IgA} \\
(\mathrm{mg} / \mathrm{l})\end{array}$ & $\begin{array}{l}\text { Haptoglobin } \\
(\mathrm{mg} / \mathrm{l})\end{array}$ & $\begin{array}{l}\text { CRP } \\
(\mathrm{mg} / \mathrm{l})\end{array}$ \\
\hline $\begin{array}{l}\text { OSCC } \\
\text { untreated }\end{array}$ & $2,8 \mathrm{p}=0,221$ & $38 \mathrm{p}=0,795$ & $152 \mathrm{p}=0,623$ & $30 \mathrm{p}=0,021$ & $0,157 \mathrm{p}=0,017$ \\
\hline $\begin{array}{l}\text { Precancerous } \\
\text { lesions }\end{array}$ & $\mathbf{2}$ & $\mathbf{7 0}$ & $\mathbf{1 6 8}$ & $\mathbf{0}$ & $\mathbf{0 , 1 1 0}$ \\
\hline Controls & $\mathbf{1 , 2} \mathbf{p}=\mathbf{0 , 2 0 5}$ & $\mathbf{2 2 p}=\mathbf{0 , 0 1 8}$ & $\mathbf{8 3 p}=\mathbf{0 , 0 4 3}$ & $\mathbf{1 5 p}=\mathbf{0 , 4 7 4}$ & $\mathbf{0 , 0 3 0}=\mathbf{0 , 4 3 4}$ \\
\hline
\end{tabular}

\section{- versus untreated OSCC:}

The salivary levels of haptoglobin and CRP were significantly higher in untreated OSCC. The other parameters did not differ significantly between these two groups (Table 5).

\section{DISCUSSION:}

According to Watanabe et al. the mucosal immune system, with its local mechanisms, appears to be independent from systematic immunity. It represents the first line of defense against the uptake of macromolecules and infectious agents in intestines, respiratory tract and genitourinary system. However, its relation to the development and control of neoplasia is not well understood, despite the fact that the most human malignancies derive from epithelial tissues and appear at sites where the secretory immune system is vigorously functioning.

In the present study the salivary levels of IgA and IgG in patients with oral squamous cell carcinoma were significantly increased, which is in accordance with the data of Brown et al. and Shpitzer et al. Although a direct transudation of $\operatorname{IgA}$ and $\operatorname{IgG}$ from the blood cannot be fully excluded, one could suppose that these findings reflect the local inflammation, accompanying the neoplastic process in oral cavity. This fact is confirmed by the high levels of the tested parameters in treated patients. On the other hand, it could be considered as being local defense mechanism against the tumor development.

Serum elevation of CRP has been reported to be an indicator of the unfavorable outcome in patients with some malignant tumors (Hirasaki et al.). It has been shown that a high CRP serum level in patients with squamous cell carcinoma is associated with tumor progression and poor survival (Gockel et al.). In the present study salivary CRP levels in patients with precancerous lesions and OSCC untreated patients were significantly elevated.

Elevated concentrations of haptoglobin are seen in various malignant diseases, including oesophageal squamous cell carcinoma (Chen et al.). Increased salivary levels of haptoglobin could be related to direct transudation from the blood. 
The elevated level of total protein in OSCC untreated patients, OSCC treated and patients with precancerous lesions and reflects, at least partly, the tendency of the above proteins to increase. This suggests a local origin of total protein in saliva in our patients.

\section{CONCLUSION}

The investigation of salivary proteins in the present study suggests the idea of their local production as an answer to the malignant process.

The practical usefulness of this constellation of proteins in saliva deserves further evaluation with a view of screening for early oral cancer, possible recurrent disease and individuals with high risk of oral malignant disease.

\section{REFERENCES:}

1. Brown, A.M., Lally ET, Frankel A, Harwick R, Davis LW, Rominger CJ. The association of the IGA levels of serum and whole saliva with the progression of oral cancer. Cancer 1975; 35:1154-62.

2. Chen, P., Zhonghua Er., Bi Yan, Hou Ke, Za Zhi. Serum acute phase proteins in nasopharyngeal carcinoma and laryngeal cancers 1989;24:174-6.

3. Christodoulides, N., Mohanty S, Miller CS, Langub MC, Floriano PN, Ali MF et al. Application of microchip assay system for the measurement of C-reactive protein in human saliva. Lab Chip 2005;5:261-9.

4. Dawes, C., Weatherell JA. Kinetics of fluoride in the oral fluids. J Dent Res. 1990;69:638-44.

5. De Souza, R.M., Lehn Cn, Denardin OV. Serumand salivary immunoglobulin A levels in patients with cancer of the mouth and oropharynx. Rev Assoc Med 2003;49:40-4.

6. Evrin, P.E., Nilsson SE, Oberg T, Malmberg B.Serum C-reactive protein in elderly men and women: association with mortality, morbidity and various biochemical values. Scand J Clin Lab Invest. 2005;65(1):23-31.)

7. Gleeson, M., Gripps AW,Clancy RL. Modifiers of thehuman mucosal immune system. Immunol Cell Biol 1995;73:397-404.
8. Gockel, I., Dirksen K, Messow $\mathrm{CM}$, Junginger T. Significance of preoperative C-reactive protein as a parameter of the perioperative course and long-term prognosis in squamous cell carcinoma and adenocarcinoma of the oesophagus. World J Gastroenterol 2006;21;12:3746-50

9. Grimoud, A.M., Pontet F, Rousselet F, Lodter JP, Duffaut D, Seguela JP. Comparison of protein concentrations in saliva and serum. Ann Biol Clin 1988;46:361-70.

10. Hirasaki, S, Yamazaki T, Shiba K. Changes in salivary components by drug administration in patients with heart diseases. J Med Dent Sci 2005;52:183-8.

11. Hu, S., Yu T, Xie Y, Yang Y, Li Y, Zhou X et al. Discovery of oral fluid biomarkers for human oral cancer by mass spectrometry. Cancer Genomics Proteomics 2007;4:55-64.

12. Kugler, J., Hess M, Haake D. Secretion of salivary immunoglobulin A in relation to age, saliva flow, mood state, secretion of albumin, cortisol, and catecholamines in saliva. J Clin immunol 1992; 12:45-9.

13. Nagler, R., Dayan D. The dual role of saliva in oral carcinogenesis. Oncology. 2006;71:10-7.

14. Parkin, M., Pisani P, Ferlay J. Estimates of the worldwide incidence of 25 major cancers in 1990. Int J
Cancer 1999;80:827-41.

15. Parra, M.D., Tecles F, MartinezSubiela S, Ceron JJ. C-reactive protein measurement in canine saliva. J Vet Diagn Invest 2005;17:139-44.

16. Shpitzer, Th., Bahar G, Feinmesser R, Nagler R M. A comprehensive salivary analysis for oral cancr diagnosis. J Cancer Res Clin Oncol 2007;133:613-7.

17. Ugrinov, R., Georgieva K, Kavlakov P, Svestarov V, Tenchev P, Bochev V et al. Malignant tumours of lips and oral mucosa. In: Maxillo Facial and Oral Surgery (in Bulgarian), Kivi Publishing Group, Sofia 2006;50916.

18. V. Vucicevic, N. Cikes, J Lukas, M Virag, A Cekic-Arambasin. Salivary and serum interleukin 6 and basic fibroblast growth factor levels in patuents with oral squamous cell carcinoma. Minerva Stomatol 2005; 54:569-73.

19. Watanabe, T., Iglehart JD, Bolognesi DP. Secretory immune response in patients with oropharyngeal carcinoma. Ann Otol Rhinol Laryngol 1983;92:295-9.

20. Zhao, C., Annamalai L, Guo C, Kothandaraman N, Koh SC, Zhang H et al. Circulating haptoglobin is an independent prognostic factor in the sera of patients with epithelial ovarian cancer. Neoplasia 2007;9:1-7.

\section{Address for correspondence:}

Asya Krasteva

Department of Oral Diagnostic and Maxillofacial Radiology, Faculty of Dental Medicine, Medical University of Sofia,

1, Georgi Sofiiski Str., Sofia, Bulgaria

E-mail: asyakrasteva@abv.bg 